Dr TOMA MILENKOVIĆ, naučni savetnik u penziji

Beograd

\title{
O BROJU RUSKIH INŽENJERA U JUGOSLAVIJI 1919-1941
}

Godine 1997. u Beogradu je štampana knjiga ovog autora Ruski inženjeri u Jugoslaviji 1919-1941. Ispala je skromna u svakom pogledu. Ima 215 stranica uključujući tu i opširan prilog, mada je obuhvaćena problematika tražila daleko više prostora. Njen sadržaj je takođe ispao skroman, jer nije bilo moguće izvršiti celovita istraživanja. Grafička oprema i lektorskokorektorska priprema je ispod svake tolerantne granice (knjiga vrvi od štamparskih grešaka od kojih neke menjaju smisao teksta) itd. Jedino su kvalitetni papir i fotografije $u$ boji. Zašto je sve pomenuto i mnogo toga nepomenutog ispalo tako? Istraživanje za monografiju, njeno pisanje i štampanje izvršeno je takoreći u najgorem vremenu - u vreme raspadanja Jugoslavije, građanskog rata u njoj, međunarodnih sankcija primenjivanih prema Saveznoj Republici Jugoslaviji, opšte krize. U takvoj situaciji nije bilo lako koncentrisati se na naučni rad. O naučnim istraživanjima izvan Srbije nije se moglo ni pomišljati, jer se u Hrvatskoj i Bosni i Hercegovini relativno dugo ratovalo. Vladala je opšta kriza i besparica. Institut za savremenu istoriju u Beogradu se teško dovijao da obezbedi redovnu isplatu ličnih dohodaka svojih saradnika. O finansiranju nekih širih istraživanja nije se moglo ni govoriti.

Još veći problemi su nastali kada su istraživanja okončana a rukopis završen i trebalo ga je štampati. Institut nije bio u stanju da to učini. Otpočelo je mukotrpno traženje sponzora. Pisac ovih redova se javljao u nekoliko institucija u Beogradu u kojima je u međuratnom periodu radio veliki broj ruskih inženjera, među njima u nekoliko ministarstava. Sa sobom je nosio pismo Instituta u kojem se govorilo o načinu nastanka i karakteru rada. Priman je uglavnom onako kako se primaju nepoželjni prosjaci kada se sa ispruženom rukom i molbom za mislostinju pojave pred vratima. I te institucije su bile $u$ besparici. To je ponižavalo i obeshrabrivalo. Pomišljao je da odustane od objavljivanja rada. Na kraju je na razumevanje naišao kod Saveza inženjera i tehničara Srbije u Beogradu. Savezu je problematika koja se $u$ knjizi tretira najbliža i normalno je što je bio zainteresovan za njeno 
štampanje. Međutim, pošto se ni njima nisu prelivala sredstva, pa da bi ih uštedeli na štampanju, tražili su od autora da već osakaćen rukopis još više skrati (odbaci neka poglavlja). Nije mogao da im izađe u susret.

Rukopis rada i kompjutersku disketu autor je predao Savezu maja 1997. Očekivao je da će ubrzo otpočeti njegovo pripremanje za štampanje. Rečeno mu je, međutim, da će štampanje biti obavljeno do kraja godine i da se ne mora žuriti. Uskoro su u julu i avgustu usledili godišnji odmori. I baš tada je za septembar zakazan kongres Saveza inženjera i tehničara. Nekome je palo na pamet da do tada treba završiti štampanje knjige Ruski inženjeri u Jugoslaviji 1919-1941. Nastala je trka sa vremenom. Pripreme su izvršene navrat-nanos i rukopis je otišao u štampu a da se piscu nije pružila prilika ni da ga prethodno pogleda. Do kongresa Saveza inženjera i tehničara posao je završen, ali se knjiga pojavila osakaćena, sa mnogim krupnim manjkavostima.

Jedna od najkrupnijih jeste nepotpuna istraženost izvora za ovu temu. Odmah treba istaći da ne postoji nijedan arhivski fond u kojem je koncentrisan veći broj dokumenata koji se odnosi na ruske inženjere, već su izvori rasuti na sve strane. Da bi se većina njih pronašla i konsultovala trebalo je utrošiti mnogo vremena. U međuratnom periodu više stotina ruskih inženjera je radilo u jugoslovenskim ministarstvima saobraćaja, šuma i ruda, poljoprivrede i voda, trgovine i industrije, građevina, vojske, finansija i brojnim direkcijama. Kada bi se danas istražila većina dosad neistraženih izvora koji se odnose na ruske inženjere u Jugoslaviji u međuratnom periodu bilo bi moguće napisati novu kompletniju knjigu, dvostruko veću od postojeće. To je ovom autoru iz mnogih razloga bilo nemoguće. Ovde želimo samo da korigujemo neke podatke koji se odnose uglavnom na broj ruskih inženjera u Jugoslaviji u međuratnom periodu, jer su oni izneti u knjizi, iz objektivnih razloga, u nekoliko slučajeva nepotpuni ili netačni. Do tih novih podataka došli smo neplanirano tokom višegodišnjeg rada na novim temama.

Na samom početku pitanje se postavlja od kuda uopšte ruski inženjeri u Jugoslaviji. Posle pobede Oktobarske socijalističke revolucije u Rusiji 1917. godine oko dva miliona njenih građana svojevoljno je napustilo zemlju i otisnulo se u svet, jer nisu želeli da žive pod vlašću boljševika. Utočište su potražili prvo u svim susednim zemljama sa kojima se Rusija graničila. Očekivali su da će boljševici brzo biti poraženi i oni se vratiti svojim kućama. Kada do toga nije došlo, rasuli su se gotovo po celoj planeti.

Prve izbeglice iz Rusije pristigle su u Srbiju ubrzo po njenom oslobođenju od okupacije, tokom novembra 1918. Do sredine januara 1921. u Jugoslaviju su se slila četiri talasa sa 32.000-35.000 civilnih izbeglica iz 
Rusije. ${ }^{1}$ Među njima su se nalazili i inženjeri. Sredinom 1920. bilo ih je 203, a sredinom aprila naredne godine u Jugoslaviji su registrovana 422 „tehnička inženjera“, 414 „inženjera specijalista“ i 107 agronoma, što sabrano iznosi 943 inženjera emigranta iz Rusije. Sami ruski inženjeri su tvrdili da ih je do sredine 1921. iz Rusije u Jugoslaviju pristiglo oko 1.200, a i dalje su pridolazili. Kolika je to masa najviših tehničkih stručnjaka bila vidi se i po tome što je Srbija pred Prvi svetski rat u granicama od Save i Dunava do Grčke imala ukupno oko 1.000 inženjera. Skoro polovina njih je stradala tokom rata (izginuli kao rezervni oficiri, pomrli po logorima interniraca i ratnih zarobljenika širom Austro-Ugarske i Bugarske ili prirodnom smrću kod svojih kuća ili prestareli i dr.). ${ }^{2}$ Od juna 1921. do kraja te godine u Jugoslaviju je prispeo peti talas izbeglica iz Rusije - vojne formacije generala Vrangela. Procenjuje se da je on doneo oko 12.000 vojnih lica. Sem pomenutih talasa, u Jugoslaviju su do sredine 1924. neprekidno, legalno i ilegalno, iz svih pravaca (Mađarske, Rumunije, Bugarske, Grčke) stizali novi pojedinci i grupe izbeglica. Među njima se takođe nalazio nepoznat broj inženjera, ali nije preterano reći da ih je bilo oko 200. Iz kasnijeg izlaganja ćemo videti da je tokom 1923. i 1924. u Kraljevinu SHS pristiglo još oko 150 ruskih inženjera, što njihov ukupan broj penje na brojku od $\mathbf{1 . 5 5 0}$.

Inženjeri su po specijalnosti bili: mašinski, građevinski, saobraćajni, vojni, hemijski, pomorski, vazduhoplovni, šumarski, tehnološki, geodetski, rudarski, geološki, elektro, hidro, mehaničarski, arhitekti, agronomi itd.

U dosadašnjem izlaganju neprekidno smo govorili o „ruskim inženjerima“. Ne postoje podaci o nacionalnoj strukturi inženjera emigranata prispelih iz Rusije u Jugoslaviju, jer njih niko nije sakupljao. Samo se po sebi razume da su Rusi, kao daleko najbrojniji narod u carskoj Rusiji, bili najzastupljeniji među inženjerima emigrantima. Pojedinačni sačuvani podaci o nacionalnoj pripadnosti, kao i imena i prezimena inženjera, pokazuju da je među njima bilo dosta Belorusa i Ukrajinaca, a daleko manje Poljaka, Jevreja, Jermena, Gruzina, Kalmika, Azerbedžanaca, Kazaha i drugih turskih naroda, kao i u manjoj ili većoj meri rusificiranih pripadnika germanskih i romanskih naroda. Kada pišemo o „ruskim inženjerima“ činimo to isključivo radi skraćivanja teksta, a uvek imamo u vidu rečeno, to jest „ruski inženjeri“ će označavati inženjere poreklom iz carske Rusije, a ne inženjere ruske nacionalnosti.

Postojala je još jedna vrlo brojna grupacija ruskih inženjera u Jugoslaviji u međuratnom periodu. Bili su to inženjeri koji su studije tehničkih nauka završili u Jugoslaviji. Ovde im izbor specijalnosti nije bio veliki kao u

${ }^{1}$ Opširno o tome: Miroslav Jovanović, Doseljavanje ruskih izbeglica u Kraljevinu Srba, Hrvata i Slovenaca 1919-1924, Beograd 1996, 97-142.

${ }^{2}$ Više u: Toma Milenković, Ruski inženjeri u Jugoslaviji 1919-1941, Beograd 1997, 8. 
carskoj Rusiji. U zemlji su postojala samo tri tehnička fakulteta - u Beogradu, Zagrebu i Ljubljani. Tehnički fakultet u Beogradu je odmah posle Prvog svetskog rata imao tri odseka - građevinski, mašinski i arhitektonski, s tim što su studenti građevine sticali neophodna znanja i iz geodezije, a studenti mašinstva iz elektrotehnike. Tehnološki odsek je otvoren školske 1921/22. a prve diplomce je dao posle četiri godine. U Sloveniji do završetka Prvog svetskog rata nije postojala nijedna srednja ili visoka škola na slovenačkom jeziku, a zatim je stvaranjem Kraljevine SHS došlo do ekspanzije školstva. Univerzitet u Ljubljani je proradio već 1919/20. godine, a u njegovim okvirima i Tehnički fakultet. Na tehničkim fakultetima u Zagrebu i Ljubljani postojali su mašinski, elektrotehnički, arhitektonski i građevinski odseci, u Zagrebu još geodetski, gospodarsko-šumarski i brodograđevinski, a u Ljubljani rudarski odsek.

Na beogradskom Tehničkom fakultetu studenti rodom iz Rusije susreću se prve posleratne školske 1919/20. godine. Jedan od njih je diplomirao već novembra 1919, a drugi godinu dana kasnije. Samo se po sebi razume da ovi studenti nisu studirali u Beogradu već u Rusiji, a ovde su samo diplomirali. Kao god što su emigranti iz Rusije težili da se nasele u istočnim delovima Jugoslavije, tamo gde je u većini živeo pravoslavni živalj, isto tako su studenti poreklom iz Rusije u velikoj većini želeli da studiraju u Beogradu. U jesen 1921. u Beogradu se sjatilo više od 1.300 ruskih studenata (samo malo više je bilo domaćih studenata) i svi su želeli da se upišu na mesni Univerzitet, najviše na Tehnički fakultet. To je bilo nemoguće zbog ograničenih prostornih i nastavnih kapaciteta Beogradskog univerziteta. Jednom ruskom organu je prepušteno da odredi koliki broj i koji će poimenično ruski studenti studirati u Beogradu, a ostali su morali da se preorijentišu na Zagreb i Ljubljanu. Na beogradskom Tehničkom fakultetu tokom 1920/21. studiralo je 50 ruskih studenata, naredne godine već 139, a 1926/27. čak 575. Dalje je broj ruskih studenata u Beogradu postupno uglavnom opadao (u Zagrebu i Ljubljani brže i više), jer se uopšte smanjivao broj ruskih studenata. U Beogradu je njihov broj 1930/31. iznosio 378, 1934/35 - 250, a 1939/40 - 290. Na Poljoprivredno-šumarskom fakultetu u Zemunu 1921/22. ruskih studenata je bilo 91, a zatim se ta brojka kretala uglavnom između 50 i 60 . $^{3}$

Tehnički fakultet u Zagrebu je 1920/21. godine imao 25 ruskih studenata, 1921/22 - 131, a 1922/23 - 166. Zatim taj broj opada pa ih 1927/28. ima 132, 1934/35 - 17, a 1939/40 svega 9. Na Poljoprivrednom fakultetu ih je bilo od 5 do 10 puta manje. ${ }^{4}$

${ }^{3}$ Više o tome: Toma Milenković, Školovanje dece emigranata iz Rusije u Jugoslaviji 1919-1941, Beograd 2004, 369-380.

${ }^{4}$ Isto, 387-389. 
Kretanje brojnog stanja ruskih studenata na Tehničkom fakultetu u Ljubljani pokazuje iste tendencije kao u Beogradu i Zagrebu. Ovde ih je 1921/22. bilo 82, 1922/23 - 110, 1926/27 - 51, 1931/32-20 i 1939/40-8. ${ }^{5}$

Prostim sabiranjem navedenih brojki dolazimo do saznanja da je na sva tri tehnička fakulteta u Jugoslaviji školske 1921/22. studiralo 157 studenata pristiglih iz Rusije, 1921/22 - 415, 1926/27 - 758, 1934/35 - 289 i 1939/40 - 306 .

Ruski studenti su bili uredniji u davanju ispita od svojih domaćih kolega, što znači da su urednije i završavali studije. Nažalost, izvori su ovde nepotpuni ili nedostaju i onemogućavaju da se ustanovi tačan broj ruskih diplomaca na pojedinim fakultetima. Najviše u tom pogledu pružaju neke jubilarne spomenice fakulteta koje, uz ostalo, sadrže i spiskove diplomiranih studenata. U tom pogledu najkvalitetniji je spisak diplomaca Tehničkog fakulteta u Beogradu zaključno sa krajem 1938. godine, ${ }^{6}$ koji, osim imena, prezimena i imena oca (imя otčestva), sadrži podatke o tome koji je odsek student završio, kada je rođen, gde je rođen (za studente iz Rusije ne samo naziv mesta nego i naziv gubernije, uz naznačenje da se mesto nalazi $u$ Rusiji). Ovde ne može biti greške u pogledu teritorijalnog porekla diplomca. (Zahvaljujući ovoj publikaciji u svršene studente Tehničkog fakulteta u Beogradu uvrstili smo i Milevu Marinkovič, osobu bez sumnje srpskog porekla, koja je 1935. okončala studije tehnologije, jer u Imeniku jasno piše da je rođena u Rusiji i otuda došla kao emigrant. Isto važi i za Danila Lončareviča koji je 1919. diplomirao građevinu na Tehničkom fakultetu u Beogradu, Jovana Vukaloviča, koji je 1928. u Beogradu takođe završio studije građevine, Mirka Dabinoviča koji je 1938. završio studije arhitekture i dr.). Sve ostale spomenice ${ }^{7}$ sadrže samo celovite spiskove sa imenima i prezimenima diplomiranih studenata. S obzirom na to da i kod nas i kod Rusa postoje ista imena (Aleksandar, Ivan, Konstantin, Vladimir, Boris, Stefan, Andrej i druga) i prezimena (Vasiljev, Ivanov, Davidov, Markov, Petrov, Popov, Sokolov, Svetozarov i druga) kada se takva imena i prezimena pojave u izvorima, bez drugih bližih određenja, nemoguće je ustanoviti da li je reč o domaćem diplomcu i inženjeru uopšte ili emigrantu iz Rusije. U tim

\footnotetext{
${ }^{5}$ Isto, 389-390.

${ }^{6}$ Imenik diplomiranih inženjera i arhitekata na Tehničkom fakultetu u Beogradu 19191938, (Beograd 1939).

${ }^{7}$ U red takvih spadaju: Gospodarsko-šumarski fakultet Sveučilišta Kraljevine Jugoslavije u Zagrebu 1919-1929, (Zagreb 1929); Tehnički fakultet Sveučilišta Kraljevine Jugoslavije u Zagrebu 1919-1929, (Zagreb 1929); Zgodovina Slovenske univerze v Ljubljani do leta 1929, (Ljubljana b. g.); Geodetski fakultet Sveučilišta u Zagrebu, Spomenica 1919-1969, (Zagreb 1970); Pedeset godina Poljoprivrednog fakulteta (u Zemunu) 1919/20-1969/70, (Beograd 1972); Monografija o razvoju i radu Tehnološko-metalulurškog fakulteta (u Beogradu) 19251975, (Beograd 1975).
} 
„sumnjivim slučajevima“ postupali smo restriktivno - „sumnjive“ nismo uračunavali u Ruse. Smatrali smo da je manji greh izostaviti iz evidencije nekog Rusa nego domaćeg diplomca ili inženjera uračunati u Ruse. Na isti način smo postupali i sa diplomcima i inženjerima koji su nosili germanska i romanska imena i prezimena, jer je takvih bilo i kod nas i kod Rusa. Taj postupak je svakako smanjio broj diplomiranih ruskih studenata i inženjera uopšte. U Jugoslaviji su neka imena Rusa često prilagođavana jeziku sredine. Tako je od Pavela postajao Pavle, od Pjotra - Petar, od Semjona Simeon, od Artjoma - Artem itd. Mi smo uglavnom ostavljali imena u onom obliku u kojem su zapisana.

Na Beogradskom univerzitetu jedino je dekan Poljoprivrednošumarskog fakulteta $u$ međuratnom periodu u tri maha izvestio rektora $o$ broju diplomiranih ruskih studenata. Iz njegovog izveštaja za školsku 1927/28. saznajemo da je te godine diplomirao ukupno 31 student, među njima i 13 Rusa i to 4 na poljoprivrednom i 9 na šumarskom odseku. Sledeće godine diplomirala su 3 Rusa na poljoprivrednom i 6 na šumarskom odseku. I konačno školske 1935/36. godine diplomirao je samo jedan Rus na poljoprivrednom i 5 na šumarskom odseku. To su jedini konkretni brojčani podaci koji se odnose na studente Poljoprivredno-šumarskog fakulteta poreklom iz Rusije. Ostali podaci potiču iz pomenute spomenice povodom 50 godina postojanja i rada fakulteta. Iz nje proizilazi da je do okupacije zemlje 1941. godine samo na poljoprivrednom odseku diplomiralo ukupno 418 studenata. Sudeći samo po imenima i prezimenima diplomaca, među njima se nalazilo 86 Rusa ( $20,57 \%$ od ukupnog broja), od kojih 10 devojaka. Najviše ih je diplomiralo 1925/26. godine - $23(67,64 \%$ od svih diplomiranih). Sledeće godine je diplomu steklo 13 Rusa $(81,25 \%){ }^{8}$

Šumarski fakultet je takođe objavio svoju spomenicu, ali ona ne sadrži spisak diplomiranih, jer je arhiva šumarskog odseka izgorela krajem Drugog svetskog rata. Priređivači spomenice su procenili da je sa fakulteta do okupacije zemlje 1941. izašlo ukupno između 600 i 700 šumarskih inženjera. Ako su ruski studenti među njima bili zastupljeni u istoj srazmeri kao među agronomima (a sve govori da ih je bilo više), značilo bi da je u tom periodu diplome šumarskih inženjera steklo oko 130 ruskih studenata. To, dalje, znači da je u međuratnom periodu na Poljoprivredno-šumarskom fakultetu u Zemunu diplomiralo oko 216 Rusa.

Zahvaljujući dragocenoj publikaciji Imenik diplomiranih inženjera i arhitekata na Tehničkom fakultetu u Beogradu 1919-1938. pouzdano znamo da su do kraja 1938. na ovom fakultetu diplomirala 464 studenta rođena na teriroriji predrevolucionarne Rusije (19,92\% od svih diplomaca). Do 1929.

\footnotetext{
${ }^{8}$ Isto, 451.
} 
diplomirala su samo 94 ruska studenta. Može se smatrati da su do 1924. fakultet završavali isključivo oni koji su studije tehnike započeli u Rusiji a u Beogradu ih nastavili i završili. Takvih je bilo malo - svega 10. Od 1924. počinju da diplomiraju uglavnom oni koji su studije započeli i završili u Jugoslaviji. Njihov broj se godišnje kretao od 12 do 24. Do naglog skoka je došlo posle 1929. kada se taj broj penje na 30 do 38 godišnje. Rekord predstavlja 1932. kada je školovanje na Tehničkom fakultetu završio 51 ruski student (36,17\% od svih diplomiranih te godine).

Za period nešto duži od dve godine pred okupaciju zemlje (koji ne obuhvata pomenuti Imenik) ne postoje pouzdani i celovito sačuvani podaci o broju diplomiranih studenata na Tehničkom fakultetu u Beogradu. ${ }^{9}$ Zbog toga se ovde moramo poslužiti slobodnom procenom. Od 1931. do kraja 1938. prosečno je na Tehničkom fakultetu godišnje diplomiralo po 37 studenata rodom iz Rusije. Ako se dinamika diplomiranja zadržala i u narednom periodu (a verujemo da jeste), onda je Tehnički fakultet u Beogradu do aprila 1941. završilo još oko 80 ruskih studenata Pouzdano se zna jedino da je u tom periodu na građevinskom odseku diplomirao 41 ruski student a na tehnološkom 8, dok su preostalih 31 diplomirali na mašinsko-elektrotehničkom odseku i arhitekturi. To znači da su od 1919. do okupacije zemlje Tehnički fakultet u Beogradu završila oko 543 ruska studenta. ${ }^{10}$

Pada u oči velika nesrazmera između broja upisanih studenata na Tehnički fakultet poreklom iz Rusije i broja diplomiralih. Naime, dvadesetih godina na sve fakultete Beogradskog univerziteta (ista pojava postoji $\mathrm{u}$ Zagrebu i Ljubljani) upisivao se daleko veći broj ruskih studenata nego tridesetih godina, a tridesetih godina je diplomirao daleko veći broj njih nego dvadesetih. Čime se može objasniti ova, na prvi pogled, paradoksalna pojava? Do nje je dovelo više uzroka, a najvažniji je taj što veliki broj ruskih đaka nije imao sistematsko školovanje tokom prethodnih 8-10 godina. Kada je započeo Prvi svetski rat i nemačke i austrougarske armije stale da prodiru u zapadne delove carske Rusije, veliki deo mesnog stanovništva nije želeo da čeka okupatora već se selio u centralnu i istočnu Rusiju. Svetski rat se još nije završio a otpočeo je građanski rat u Rusiji, koji je doveo do još većih unutrašnjih seoba stanovništva. Jedni su bežali ispred „belih“, drugi ispred "crvenih". U tom periodu je došlo prvo do malobrojnog a zatim sve masovnijeg bežanja ruskog stanovništva u inostranstvo. Najmasovniji egzodus se desio u drugoj polovini 1920. i 1921. i prvoj polovini 1922. godine. U

${ }^{9}$ Na Tehničkom fakultetu je i od 1939. do 1946. vođena Knjiga diplomiranih studenata Tehničkog fakulteta. Sve do početka 90 -ih godina ona je „šetala“ sa fakulteta na fakultet naslednika bivšeg Tehničkog fakulteta. Koristili su je pisci spomenica tih fakulteta. A onda se negde zaturila i pisac ovih redova nije uspeo da je pronađe, iako je to uporno pokušavao u dva navrata.

${ }^{10}$ T. Milenković, Školovanje dece emigranata iz Rusije u Jugoslaviji, 452-454. 
takvim uslovima nije moglo da bude ni govora o sistematskom školovanju ruskih đaka. To naročito važi za period od napuštanja ruske teritorije do dolaska u Jugoslaviju i sticanja kakvog-takvog smeštaja i uslova za golo preživljavanje. U tom periodu ruski đaci su prekidali svaku vezu sa školom. Mnogi ruski učenici i studenti prispeli u Jugoslaviju bili su prestareli, jer su prethodno godine proveli u ruskoj armiji i „belim“ formacijama ratujući. (Mnogi su stekli visoka ratna odlikovanja). Takvima ili nije dozvoljeno dalje školovanje, ili, ako jeste, imali su velike teškoće da se ponovo uključe u nastavni proces. Ne treba izgubiti iz vida velike razlike između nastavnih programa srednjih škola u Rusiji i u jugoslovenskim zemljama. Mnogo toga što se učilo u srednjim školama u Rusiji nije bilo korisno u novoj sredini i obrnuto. Zatim, trebalo je da protekne izvesno vreme da bi pridošlice iz Rusije dovoljno savladale jezik lokalne sredine, da bi mogle da uče iz jugoslovenskih udžbenika i da se izražavaju na srpskohrvatskom i slovenačkom jeziku. I na kraju, veliki broj ruskih studenata pristigao je u Jugoslaviju bez svojih porodica. Oni su bili prepušteni sami sebi, da se snalaze u životu kako znaju i umeju. Upisivali su se na fakultete i dobijali minimalne stipendije, nedovoljne za zadovoljenje najneophodnijih životnih potreba. Da bi mogli da opstanu morali su da se dovijaju (da rade) i pribavljaju dodatna srdstva. To ih je, uz pomenute teškoće, udaljavalo od fakulteta i učenja, što je produžavalo studiranje. Mnogi nisu uspevali da se izbore sa svim tim problemima nego su napuštali studije. Sve to i mnogo šta drugo uticalo je da se pojavi pomenuta nesrazmera.

Ruski studenti diplomci u Beogradu nisu bili ravnomerno raspoređeni po svim odsecima Tehničkog fakulteta. Najviše ih je do kraja 1938. diplomiralo na građevinskom odseku - 201. Zatim slede mašinsko-elektrotehnički sa 154, arhitektonski sa 86 i daleko na začelju tehnološki odsek sa svega 23 diplomirana ruska studenta. Poslednje cifre zaslužuje izvesno objašnjenje. Kada je posle Prvog svetskog rata Tehnički fakultet obnovio rad na njemu su postojala samo prva tri odseka. Tehnološki odsek je naknadno ustrojen i prve diplomce je dao 1925. godine. Prvi Rus je na njemu diplomirao oktobra 1927, a sledeći februara 1930. Taj odsek u domaćoj sredini još nije bio prihvaćen. U početku studenti nisu videli perspektivu za inženjere tehnologije. Međutim, 30-ih godina odnos prema tehnologiji se dosta promenio u pozitivnom smislu. I ruski diplomirani arhitekti zaostaju po brojnosti za građevinskim i elektro-mašinskim inženjerima. Ovde se nije radilo o razlozima navedenim kod tehnologa, pošto je profesija arhitekata bila jako cenjena i prestižna. U pitanju su bili pretežno ekonomski razlozi. Svaki student arhitekture morao je da uloži dosta sredstava za nabavku različitih crtaćih i drugih pribora, a kasnije za kupovinu raznovrsnih materijala. Prvih godina među ruskim studentima koji su dolazili na Tehnički fakul- 
tet dominantnu većinu su činili oni koji su živeli od nedovoljno visokih stipendija Državne komisije, tako da im za vanredne izdatke nije ništa preostajalo. Zbog toga je 1923, 1924, 1926. i 1927. na ovom odseku diplomirao samo po jedan ruski student. Tek 1928. godine, kada su na ovaj odsek dospeli uglavnom studenti čiji su roditelji živeli u Jugoslaviji i bili u stanju da ih finansijski podržavaju, na arhitekturi je diplomiralo 9 ruskih studenata.

Nekada je Tehnički fakultet bio takoreći „muški“ fakultet. Ruski studenti i studentkinje su u tom pogledu veoma malo promenili već stvorenu sliku. Od 464 diplomirana ruska studenta na ovom fakultetu do kraja 1938. samo su 14 bile devojke. Prva od njih diplomirala je 1925, druga 1928. godine, obe na građevinskom odseku. One su ostale jedine Ruskinje koje su u međuratnom periodu završile građevinu u Beogradu. Na elektromašinskom odseku uopšte ih nije bilo. Arhitekturu je završilo njih 8 (prva 1932), a tehnologiju $4 .{ }^{11}$

Beogradski univerzitet nije radio tokom okupacije, to jest nisu držana predavanja, upisivani i overavani semestri i sl., ali je nekih aktivnosti ipak bilo. Prema odluci šefa Upravnog štaba nemačkog vojnog zapovednika Srbije, od septembra 1942. pravo polaganja ispita na fakultetima imali su isključivo studenti sa overenih osam semestara. Dakle, polagali su se uglavnom završni i diplomski ispiti. Na diplomske ispite su izlazili studenti koji su to pravo stekli uglavnom pre okupacije zemlje, zbog čega ćemo i njihove rezultate uzeti u obzir. Na Tehničkom fakultetu nije bilo ispita u junskom i oktobarskom roku 1941. godine. Sledeće, 1942. godine na građevinskom odseku diplomiralo je svega 26 studenata od kojih su $12(46,15 \%)$ bili ruskog porekla. U isto vreme diplomu tehnologa je stekao samo jedan ruski student. Za arhitektonski i elektro-mašinski odsek takvi podaci nisu sačuvani, ali ako su i ovih godina nastavljena kretanja iz prethodnog perioda, na oba odseka nije diplomirao više nego po jedan student ruskog porekla. To znači da je tokom okupacije do jeseni 1942. na Tehničkom fakultetu u Beogradu diplomiralo oko 15 ruskih studenata. ${ }^{12}$ Sa onih 543 diplomiranih do okupacije to čini oko 558 ruskih diplomaca inženjera..

Sudbina Poljoprivredno-šumarskog fakulteta tokom okupacije razlikovala se od sudbine svih ostalih fakulteta Beogradskog univerziteta. Pošto se fakultet u Zemunu zatekao na teritoriji novoosnovane, prema Srbima genocidne, Nezavisne Države Hrvatske, morao je da se iseli iz svoje nove zgrade. Inventar, biblioteku, arhivu i ostalu imovinu smestio je u prostorije današnjeg Filološkog fakulteta u Beogradu. Tu je vladala velika teskoba. Najveći dao fakultetske arhive izgoreo je pred oslobođenje Beograda, tako da se ne zna da li je koji student ruskog porekla tokom okupacije do jeseni

\footnotetext{
${ }^{11}$ Više o svemu napred izloženom: Isto, 453-454.

${ }^{12}$ Isto, 454-455.
} 
1942. stekao diplomu agronoma ili šumarskog inženjera. U svakom slučaju, kada se saberu brojke od $\mathbf{5 5 8}$ diplomiranih na Tehničkom fakultetu i 216 diplomiranih na Poljoprivredno-šumarskom fakultetu dolazi se do impozantne brojke od $\mathbf{7 7 4}$ ruskih studenata koji su u Beogradu i Zemunu stekli diplome inženjera.

Sačuvani su kompleti godišnjaka Sveučilišta u Zagrebu od školske 1924/25. do zaključno 1938/39. godine sa izveštajima svih fakulteta. U njima su dati detaljni statistički podaci o broju upisanih studenata po fakultetima, o ispitima i diplomskim ispitima. Sve je to, međutim, prezentirano uglavnom zbirno (u ciframa), tako da se tu ruski studenti ne vide. Fakulteti u Zagrebu su takođe posle Drugog svetskog rata objavljivali spomenice, ali one nisu uvek snabdevene spiskovima diplomaca, a one koje takve spiskove sadrže ne ukazuju na geografsko poreklo i nacionalnu pripadnost diplomaca, zbog čega se susrećemo sa pomenutim teškoćama.

Najviše studenata emigranata iz Rusije $u$ Zagrebu bilo je na Tehničkom fakultetu, pa je logično da ih je tu najviše i diplomiralo. Nažalost, sačuvani izvori nisu uvek kompletni i za našu temu korisni. Na mašinskom i brodograđevinskom odseku u međuratnom periodu je diplomiralo 30 Rusa, i to 2 brodograđevinarstvo a svi ostali mašinstvo. Na geodetskom odseku takođe je diplomiralo 30 studenata rodom iz Rusije. Na elektrotehničkom odseku u celokupnom međuratnom periodu diplomiralo je 5 ruskih studenata. Ne zna se koliko je emigranata iz Rusije uspešno završilo studije na arhitektonskom, građevinskom i hemijsko-inženjerskom odseku, ali ih ukupno nije moglo biti manje od 50 . Značilo bi to da je Tehnički fakultet $\mathrm{u}$ Zagrebu između dva svetska rata okončalo najmanje 115 ruskih studenata. ${ }^{13}$

Poljoprivredno-šumarski fakultet u Zagrebu je izvestio da je na njegovom agronomskom odseku od 1933. do 1939. diplomiralo 8, a na šumarskom odseku 5 ruskih studenata. Spomenica ovog fakulteta, međutim, pokazuje (sudeći po imenima i prezimenima) da je samo na njegovom agronomskom odseku od 1929. do 1941. diplomiralo 29 ruskih studenata (taj broj je svakako bio veći). S obzirom na činjenicu da je na fakultetu gotovo neprekidno bilo više studenata šumarstva nego agronomije, može se pretpostaviti da su studenti ruskog porekla u istom periodu imali oko 35 diplomaca, što znači da je ceo fakultet od 1929. do 1941. dao oko 64 ruska agronomska i šumarska inženjera. Period 20-ih godina je kraći od prethodnog ali je karakterističan po daleko većem ukupnom broju ruskih studenata, što je za sobom povuklo i veći broj diplomiranih. Procenjujemo da je tada na oba odseka diplomiralo oko 20 studenata rođenih u Rusiji. To bi značilo da je na

\footnotetext{
${ }^{13}$ Isto, 458-459.
} 
Poljoprivredno-šumarskom fakultetu u Zagrebu između dva svetska rata diplomiralo oko 84 studenta poreklom iz Rusije. ${ }^{14}$

Saberemo li broj ruskih studenata koji su diplomirali na Tehničkom fakultetu (115) i Poljoprivredno-šumarskom fakultetu (84) u Zagrebu dolazimo do brojke od oko 200 studenata rodom iz Rusije koji su u periodu između dva svetska rata u Zagrebu stekli diplome inženjera.

Za Univerzitet u Ljubljani raspolažemo sa izuzetno malo podataka o broju diplomiranih ruskih studenata. Pouzdano znamo da je na elektrotehničkom odseku Tehničkog fakulteta od 1925. do 1941. diplomiralo 8 ruskih studenata, na arhitektonskom i geodetskom odseku po 2 i na građevinskom odseku 10, ili svega 22 ruska diplomca. Po broju ruskih studanata rudarski i hemijsko-tehnološki odsek su neznatno zaostajali za elektrotehničkim odsekom. Procenjujemo da je na njima diplomiralo 12-14 studenata. To znači da je na celom Tehničkom fakultetu u Ljubljani u međuratnom periodu diplomiralo između 34 i 36 ruskih studenata. ${ }^{15}$

Rekapituliramo li izložene brojke (Beograd i Zemun oko 774, Zagreb oko 200 i Ljubljana oko 35 dolazimo do brojke od oko 1.009 ruskih studenata koji su u međuratnom periodu u Jugoslaviji stekli diplome inženjera. Ako se ovom broju doda oko 1.550 inženjera koji su kao takvi u Jugoslaviju prispeli iz Rusije, dolazimo do impozantne brojke od oko 2.559 ruskih inženjera. Naravna stvar, nijednog trenutka nije se njih toliko nalazilo u Jugoslaviji, samo ih je toliko registrovano u zemlji u celom međuratnom periodu. Videli smo već da su oni dosta masovno napuštali Jugoslaviju od početka 20-ih godina, a s tom praksom su nastavili i u narednoj deceniji. $\mathrm{U}$ vreme kada ruski inženjeri emigranti stvaraju u Jugoslaviji svoje prve organizacije, neki budući ruski inženjeri (koji će inženjerske diplome steći u našoj zemlji), još su bili deca. Deo njih će po završetku školovanja takođe napustiti Jugoslaviju. Može se reći da je prosečan stvaran broj prisutnih ruskih inženjera u Jugoslaviji iznosio oko $\mathbf{1 . 5 0 0 .}$

Stigavši u Jugoslaviju, prvi begunci iz Rusije su se sukobili sa mnogobrojnim teškoćama; na prvom mestu sa materijalnom neobezbeđenošću i krajnje neizvesnom budućnošću. Malobrojne izbeglice iz prvih talasa prihvatale su razne privatne dobrotvorne i humanitarne organizacije i starale se o njima. Ta pomoć je bila dragocena ali nedovoljna, nesigurna i neredovna. Treba imati u vidu da je Prvi svetski rat upravo završen i da je Srbija u njemu pretrpela strahovite ljudske i materijalne žrtve. Zemlja se bukvalno nalazila u ruševinama. Jugoslovenska država kao institucija uključila se u prihvat izbeglica tek kada su begunci iz Rusije počeli da pristižu u masama, to jest u proleće 1920. godine. Do tada je trebalo opstati. Kako je najveći

\footnotetext{
${ }^{14}$ Isto, 458-459.

${ }^{15}$ Isto, 460-461.
} 
broj emigranata napustio Rusiju u žurbi, nije imao mogućnosti da ponese sa sobom vredniju imovinu (dragocenosti i novac), pa čak ni lične dokumente (npr. diplome o završenoj školi). Da bi obezbedili osnovna sredstva za sopstveni život i život svojih porodica, ti ljudi su morali da se prihvataju svakog posla koji im je osiguravao bilo kakav izvor prihoda i održavanje životne egzistencije. (Neki inženjeri su radili kao nekvalifikovani fizički radnici). To pak znači da su im zarade bile mizerne.

Sve je to prinudilo ruske inženjere da izlaz traže u samopomoći i organizaciji. Njihova dogovaranja u Beogradu počela su aprila 1920. i trajala do 20. juna iste godine, kada je održana osnivačka skupština Saveza ruskih inženjera u Kraljevini SHS (SRIJ) u prisustvu 70 inženjera. Tom prilikom je usvojen Statut organizacije. Njime je između ostalog predviđeno: da Savez zastupa interese ruskih inženjera pred jugoslovenskim i ruskim vlastima, da pomaže ruskim inženjerima da na najbolji način iskoriste svoja stručna znanja i iskustva u jugoslovenskoj nauci i privredi i da ih materijalno pomaže. Statut je u narednih dvadesetak godina više puta menjan i dopunjavan kako bi njime bile obuhvaćene sve aktivnosti SRIJ. Izuzimajući šumarske inženjere i agronome Savez je postepeno okupio u jedinstvenoj organizaciji inženjere svih ostalih specijalnosti (Rusi ih nazivaju „tehnički inženjeri“).

Osnivačka skupština je izabrala upravu Saveza na čelu sa predsednikom Eduardom Bronislavovičem Vojnovskim-Krigerom, saobraćajnim inženjerom i inženjerom tehnologije i zamenicima predsednika Georgijem PioUljskim, inženjerom mehanike i univerzitetskim profesorom i Petrom Petrovičem Jurenjevom. U upravu su izabrana još četiri člana i pet njihovih zamenika. Na čelo SRIJ izabrane su ličnosti koje su u tom trenutku mogle najviše da mu pomognu u svakom pogledu u jugoslovenskoj i ruskoj sredini. Vojnovski-Kriger (1870-1933), poznati inženjer i još poznatiji privrednik i političar, obavljao je do Prvog svetskog rata visoke rukovodeće funkcije na ruskim železnicama, da bi 1915. postao zamenik a naredne godine ministar saobraćaja Rusije. Uspeo je da u inostranstvo prebaci deo kapitala Vladikavkaskih železnica kojim je pomagao SRIJ. U Jugoslaviji je obavljao i druge značajne funkcije u ruskoj emigraciji, ali i ruskoj emigraciji na međunardnom nivou. Bio je stručno sposoban, energičan, autoritativan, dobar organizator i široko uticajna ličnost. Njegovu reč su slušali i uvažavali ne samo Rusi u izbeglištvu nego i jugoslovenski merodavni faktori.

Prvi zamenik predsednika SRIJ, Pio-Uljski (1864-1938), radio je do odlaska u emigraciju kao univerzitetski profesor na više ruskih univerziteta i instituta. Početkom školske 1920/21. godine, kao poznati naučnik i iskusni univerzitetski profesor, postavljen je za profesora Tehničkog fakulteta u Beogradu. U Jugoslaviji je obavljao više važnih naučnih, privrednih i političkih funkcija. 
SRIJ je redovno održavao godišnje skupštine i na njima, između ostalog, birao nove članove u proširenu upravu (koja je jedno vreme imala 15 članova). Kroz upravu je do kraja 1938. godine prošlo 85 ruskih inženjera, što znači da je u ovom organu postojala velika fluktuacija njegovih članova. Da bi između uprave i članstva postojala stalna i čvrsta veza rešeno je da se od početka 1922. pokrene savezni organ Bюlletenъ (Bilten), koji je trebalo da izlazi mesečno ali su se zbog besparice 1922. pojavila samo četiri broja, 1923. nijedan, 1924. izašla su dva broja, a poslednji sedmi broj je objavljen 1925. godine. Za nas je Bilten dragocen je jer je u svakom broju donosio imena inženjera koji su pristupili Savezu (u prvom broju 357 imena) ili imena svih članova Saveza, odakle smo ih preuzli i objavili u prilogu ovog teksta. Kada je prestao da izlazi Bilten pokrenut je časopis Inženerъ. On nije sistematski donosio spiskove sa imenima ruskih inženjera ali ih pominje u različitim kontekstima. ${ }^{16}$

Dosta podataka o životu i radu organizacija SRIJ i imena ruskih inženjera pojedinaca $\mathrm{u}$ Jugoslaviji nalazi se u ruskim dnevnim listovima štampanim u Beogradu: Russkar gazeta (Ruske novine, 1920), Novoe vrems (Novo vreme, 1921-1929), Russkiŭ golos (Ruski glas, 1931-1941), Novblŭ putъ (Novi put, 1942-1944), kao i u 17 svezaka publikacije Zapiski Russkago naučnago instituta vъ Belgrade (1930-1941). Časopisi Tehnički list (19191939) i Inženjer (1940), organi Udruženja jugoslovenskih inženjera i arhitekata, vrlo su informativni kada su u pitanju ruski inženjeri. Beogradski dnevni listovi na srpskom jeziku, a naročito Politika, Pravda i Vreme takođe su poklanjali dosta veliku pažnju ruskim inženjerima i arhitektima. Njihova obaveštenja postaju naročito dragocena tridesetih godina, kada se pisana reč ruskih inženjera proređuje ili potpuno nestaje. Iz svih pomenutih publikacija, i mnogih drugih nepomenutih, preuzimali smo imena ruskih inženjera i uključivali ih u spisak u prilogu.

Brojno stanje ispravnih članova SRIJ (koji su platili članarinu za celu godinu)

\begin{tabular}{|c|c|c|c|}
\hline Godina & $\begin{array}{c}\text { Br. članova u } \\
\text { zemlji }\end{array}$ & $\begin{array}{l}\text { Br. članova } \\
\text { van zemlje }\end{array}$ & Svega \\
\hline 1920 & 138 & 2 & 14 \\
\hline 1921 & 347 & - & 34 \\
\hline 1922 & 460 & - & 4 \\
\hline 1923 & 417 & 89 & 50 \\
\hline 1924 & 436 & 89 & 52 \\
\hline 1925 & 349 & 98 & 44 \\
\hline 1926 & 309 & 107 & 41 \\
\hline 1927 & 309 & 109 & 41 \\
\hline 1928 & 317 & 104 & 42 \\
\hline 1929 & 330 & ? & \\
\hline
\end{tabular}

${ }^{16}$ Opširno o organizacionom razvitku SRIJ: T. Milenković, Ruski inženjeri u Jugoslaviji 1919-1941, 11-25. 
Savez je do kraja 1924. uvećavao broj svojih članova, zatim je nastalo prvo opadanje a potom stagniranje. Do daljeg opadanja članstva došlo je $\mathrm{u}$ vreme Velike ekonomske krize, koja je u Jugoslaviji trajala do pred kraj 1934. Godine 1931. SRIJ je imao 366, 1934. - 260, a 1938. - 350 članova. Prikazana tabela traži objašnjenje. Što se tiče „ispravnih članova u zemlji“ tu je sve jasno, objašnjenje zahteva druga kolona „ispravni članovi van zemlje“. To su oni inženjeri koji su početkom kalendarske godine izmirili saveznu članarinu za celu godinu (ili pola godine) a uskoro zatim posredovanjem SRIJ otišli u inostranstvo na rad. Njih je uprava SRIJ tretirala kao svoje članove sve do datuma do koga su uplatili članarinu. Tabela, dalje, pokazuje da je od 1923. do kraja 1928. iz Jugoslavije otišlo u inostranstvo 596 ruskih inženjera članova SRIJ. ${ }^{17}$

To nisu jedini ruski inženjeri koji su napustili Jugoslaviju. Mnogi nečlanovi SRIJ otišli su iz zemlje $u$ „sopstvenoj režiji“, na sugestiju ili poziv svojih kolega i prijatelja koji su to ranije učinili. U inostranstvo su ih privlačili povoljniji uslovi rada i bolje zarade. Rasuli su se takoreći po celoj Zemljinoj kugli, a naročito su odlazili u Francusku i SAD, a zatim Kanadu, Venecuelu, Brazil, Argentinu, Čile, Južnu Afriku, Indiju, Australiju i druge zemlje.

Od sredine 20-ih godina u članstvo SRIJ stupaju mladi ruski inženjeri koji su studije tehničkih nauka završili u Jugoslaviji. Od druge polovine 30-ih godina njih susrećemo i u rukovodstvu SRIJ. I oni su odlazili u inostranstvo u potrazi za boljim zaradama.

Rekli smo već da je SRIJ okupljao „tehničke inženjere“. Izvan njihovih redova ostali su šumarski i poljoprivredni inženjeri (agronomi). Smatralo se da se oni bitno razlikuju od ostalih inženjera i da je njihova aktivnost vezana za poljoprivredu i selo. Organizaciono su povezivani sa veterinarima. Njih je bilo daleko manje od „tehničkih inženjera“, ugled im je bio skromniji, a aktivnosti ograničenije i spolja manje vidljive. Oni nisu imali svojih glasila, o njima se uopšte manje pisalo u ruskoj i jugoslovenskoj štampi i periodici, a kako je malo i arhivskih podataka, to su i naša znanja o njima dosta skromna.

Ruski agronomi, veterinari i šumarski inženjeri, emigranti u Jugoslaviji, u mnogo čemu su doslovno kopirali iskustva i praksu „tehničkih inženjera", prosto sledeći njihov primer sa određenim vremenskim zakašnjenjem. Posle dužih savetovanja i priprema sastali su se 6. januara 1921. u Beogradu i osnovali Savez agronoma, veterinara i šumarskih inženjera (SAVŠI), usvojili njegova Pravila (Statut) i izabrali upravu. Na čelo Saveza je došao Aleksandar Ivanovič Stebut, profesor Poljoprivrednog fakulteta u

\footnotetext{
${ }^{17}$ Isto, 18-47.
} 
Zemunu, za njegovog zamenika je izabran V. T. Šacki, šumarski inženjer a za sekretara I. E. Anenkov. Početkom oktobra 1921. SAVŠI je imao 134 člana, a krajem 1922. godine 195 članova. U poslednjem slučaju najviše je bilo organizovanih agronoma - 109, a daleko manje šumarskih inženjera - 23. SAVŠI je još izvesno vreme organizaciono blago napredovao (u drugoj polovini 1924. imao je više od 200 članova) a zatim je nastupila stagnacija i opadanje, najviše zbog odlaska ruskih poljoprivrednih stručnjaka iz Jugoslavije $\mathrm{u}$ inostranstvo. Organizacija se do kraja 20 -ih godina sve ređe pominje, a zatim se potpuno gubi. ${ }^{18}$

Manji broj ruskih inženjera bio je član Udruženja jugoslovenskih inženjera i arhitekata i Udruženja jugoslovenskih agronoma. Izuzetak predstavljaju ruski agronomi. Njih je 1937. godine u Udruženju jugoslovenskih agronoma bilo 93 (14,88\% od ukupnog broja). U međuvremenu je u raznim kontekstima pomenuto još 29 ruskih agronoma, što njihov broj penje na brojku od 122. Podsećamo da je SAVŠI u drugoj polovini 1924, kada se nalazio na vrhuncu, imao više od 200 članova. Neki od ruskih inženjera i agronoma su istovremeno pripadali ruskim (SRIJ i SAVŠI) i jugoslovenskim organizacijama. ${ }^{19}$

Organizacije SRIJ i SAVŠI nisu bile same sebi cilj već su imale više drugih važnih zadataka. Jedan od najvažnijih bio je da pomognu zapošljavanje ruskih inženjera emigranata u Jugoslaviji. Najvažniji i neodložan posao prve uprave SRIJ bio je upravo da se postara za hitno zaposlenje što većeg broja svojih kolega. Delujući vrlo umešno i energično, ona je taj posao obavila u rekordno kratkom roku, na najbolji način i na opšte zadovoljstvo. Njeni ugledni članovi posećivali su razna ministarstva i druge visoke institucije u Beogradu, koje su zapošljavale visokostručne tehničke kadrove i preporučivale im svoje kolege. Postignuti su neočekivano dobri rezultati. Zahvaljujući tome što se tada u Jugoslaviji (a naročito njenim istočnim delovima) osećala velika potreba za inženjerima raznih specijalnosti, ali i preporukama uprave SRIJ, u ministarstvima, raznim direkcijama, upravama, okruzima, srezovima, opštinama i raznim privatnim preduzećima, uprkos jezičkim teškoćama (Rusi ne poznaju jezik sredine u koju su došli) zaposlene su stotine ruskih inženjera.

Konkretno, početkom 1921. godine u Ministarstvu građevina je dobilo zaposlenje 90 ruskih inženjera i arhitekata, razmeštenih po svim njegovim odeljenjima i odsecima. U isto vreme u Ministarstvu saobraćaja je radilo 65 ruskih inženjera sa izgledom da još 60 njih dođe do zaposlenja. Oko 40 ruskih saobraćajnih inženjera radilo je u unutrašnjosti Jugoslavije po tehničkim odeljenjima opština, železničkim sekcijama i drugim lokalnim

\footnotetext{
${ }^{18}$ Isto, 25-27.

${ }^{19}$ Isto, 27.
} 
državnim i samupravnim ustanovama. U ministarstvima trgovine i industrije, šuma i ruda i finansija u svakom ponaosob radile su desetine ruskih inženjera. Po ugledu na SRIJ uprava SAVŠI je takođe agilno radila na uposlenju agronoma i šumarskih inženjera. Samo u Ministarstvu poljoprivrede i voda do kraja 1921. zaposleno je 85 agronoma i daleko manji broj šumarskih inženjera. Kroz Generalnu direkciju voda istog ministarstva do 1930. prošlo je 55 ruskih hidroinženjera. U Jugoslaviji je 1930. godine radilo oko 50 organizovanih ruskih rudarskih inženjera. Više stotina visokih tehničkih stručnjaka osposobljenim u Rusiji za rad na najrazličitijim poslovima u aviogradnji, brodogradnji, stručnjaka za izradu artiljerijskih oruđa i uopšte naoružanja, eksploziva našli su zaposlenje u Jugoslaviji najviše pri Ministarstvu vojske i mornarice. ${ }^{20}$

Krajem 1921. i tokom 1922. u Jugoslaviji nije bilo nezaposlenih ruskih agronoma. Slična situacija je bila i sa "tehničkim inženjerima“. U pogledu zaposlenosti inženjera Jugoslavija je postala neka vrsta obećane zemlje. O tome se čulo i u inostranstvu. Sačuvani su brojni podaci koji pokazuju da pojedinci i grupe ruskih inženjera iz Turske, Bugarske, Rumunije, Poljske, Mađarske i Austrije, koji su tamo već imali kakav-takav posao, stižu u Jugoslaviju i dobijaju zaposlenje, ali njihov ukupan broj nije poznat (procenili smo da ih je bilo više od 150).

Prve poslove oko zapošljavanja ruskih inženjera emigranata obavila je uprava Saveza. Kako je taj posao bio zamašan a malobrojna uprava imala i druge obaveze i nije mogla da odgovori na sve strane, pri upravi je 1921. formiran besplatni biro rada od šest članova. Biro je odmah nastojao da stvori kompletnu informativnu dokumentaciju o svim ruskim inženjerima u Jugoslaviji, zaposlenim i nezaposlenim, organizovanim i neorganizovanim. Stoga je početkom 1922. izradio anketni list, koji je, sem ličnih i porodičnih podataka, tražio podatke o školskoj i stručnoj spremi, specijalnosti, radnom iskustvu, trenutnom zaposlenju i željama zainteresovanog u budućnosti. Birou su se obraćali svi iz Jugoslavije i inostranstva (nešto kasnije) kojima je bila potrebna visokostručna tehnička radna snaga - služio je kao spona između zainteresovanih poslodavaca i posloprimaca. ${ }^{21}$

Naglasili smo da je veliki broj izbeglica iz Rusije napustio zemlju u žurbi i sa sobom nije poneo nikakve lične dokumente i stručne diplome. To važi i za inženjere. Oni su u Jugoslaviji imali velike probleme, a naročito pri zaposlenju, jer niko nije hteo da zaposli ruskog inženjera samo na njegovu tvrdnju da je završio odgovarajuću visoku školu. Međunarodnim pravom je predviđeno da nedostajuće dokumente izbeglicama izdaje odgovarajuće diplomatsko predstavništvo njihove zemlje. Jugoslavija sve do pred Drugi

\footnotetext{
${ }^{20}$ Isto, 69-75.

21 Isto, 69-70.
} 
svetski rat nije imala diplomatske odnose sa SSSR-om, ali je u Beogradu postojalo diplomatsko predstavništvo iz perioda carske Rusije. Njegovi kapaciteti su bili jako ograničeni a broj izbeglica ogroman, tako da nije moglo da odgovori potrebama emigranata. Zbog toga je carsko diplomatsko poslanstvo to svoje pravo prenelo na SRIJ i druge stručne organizacije emigranata iz Rusije u Jugoslaviji. Uprava SRIJ je brzo formirala posebnu komisiju, koja je na osnovu drugih dokumenata, izjava lica lično poznatih Savezu, ali i na osnovu provere znanja zainteresovanih, izdavala odgovarajuća uverenja ruskim inženjerima, tehničarima i studentima tehnike. Radila je vrlo savesno tako da nije zabeležen nijedan promašaj. Ruski inženjeri nisu primani u službu bez tih uverenja i bez preporuka Saveza o stručnoj sposobnosti, radnom iskustvu i ljudskim kvalitetima kandidata.

Kada je neku godinu kasnije između Jugoslavije i Sovjetskog Saveza uspostavljen uredan poštanski saobraćaj, ruski inženjeri su od fakulteta i instituta na kojima su diplomirali tražili da im pošalju odgovarajuće diplome. Ovi su im izlazili u susret. Savet Tehničkog fakulteta u Beogradu je od 1928. do 1939. nostrifikovao 138 ovakvih diploma. Sačuvani su spiskovi vlasnika ovih diploma. Realno je pretpostaviti da su isti posao obavljali tehnički fakulteti u Zagrebu i Ljubljani, ali dokumentaciju o tome nismo pronašli. ${ }^{22}$

SRIJ se pokazao kao glomazna organizacija koja nije mogla adekvatno da zastupa interese svih inženjerskih specijalnosti u svojim redovima. Zbog toga počev od 1923. godine u okviru SRIJ niču sekcije rudarskih, vojnih, saobraćajnih, građevinskih, geodetskih, hidro inženjera, arhitekata i profesora tehničkih fakulteta. U okviru SAVŠI stvorene su sekcije šumarskih inženjera i agronoma. Sve sekcije su povremeno donosile podatke o broju svojih članova, a kroz njihove uprave je prošlo stotinu inženjera koji su poimenično pomenuti. ${ }^{23}$ Sve nam to pomaže da dođemo do približno tačnog broja ruskih inženjera u Jugoslaviji u pojedinim periodima kao i do novih imena ovih inženjera. Sem toga, pomenuli smo i neke druge oblasti aktivnosti ruskih inženjera emigranata, kao i različite izvore koji pružaju podatke ne samo o broju ruskih inženjera nego donose i imena velikog broja njih.

Spisak ruskih inženjera emigranata u Jugoslaviji 1919-1941 je objavljen u više puta pominjanoj knjizi Ruski inženjeri u Jugoslaviji 1919-1941, i sadrži imena 1.811 ruskih inženjera. Posle navedenih proširenih i produbljenih istraživanja taj spisak je obogaćen sa 337 novih imena i sada ima 2.148 imena ruskih inženjera koji su duže, kraće ili neprekidno živeli i radili u Jugoslaviji u međuratnom periodu. Naročito smo do mnogo novih

\footnotetext{
${ }^{22}$ Isto, 70-73.

${ }^{23}$ Opširno o tome: Isto, $48-57$.
} 
podataka došli pregledanjem ruske emigrantske štampe izdavane u Beogradu tokom Drugog svetskog rata. Ti listovi su takoreći neprekidno objavljivali spiskove (sa imenima, prezimenima, srednjim slovom i zanimanjem) Rusa koji su tokom okupacije iz Srbije odlazili na rad u Nemačku. Među tim imenima našao se veliki broj ruskih inženjera od kojih mnogi ranije nisu pomenuti ni u kakvom kontekstu (pa i oni koji su imali ista imena kao i domaći ljudi, koja su se susretala i na ovim prostorima). Na rad u Nemačku su svakako odlazili ruski inženjeri iz Makedonije, Vojvodine, Hrvatske, Crne Gore, Bosne i Hercegovine i Slovenije ali njihova imena nisu dospela na stranice ruske emigrantske štampe u Beogradu. Već smo procenili da je ukupan broj ruskih inženjera u Jugoslaviji u međuratnom periodu dostigao brojku od oko 2.559. Znači da u dopunjenom spisku nedostaju imena oko 411 inženjera. To su oni inženjeri koji su imali ista imena i prezimena koja se javljaju i u Jugoslaviji, zatim inženjeri koji su do rata (i početkom rata) živeli i radili van Srbije, koji nisu bili članovi ruskih inženjerskih organizacija, čija su se imena retko (ili nisu nikako) pominjala u izvorima i slični. 